\title{
PENGARUH SELF EFFICACY TERHADAP AUDIT JUDGEMENT DENGAN SENIORITAS AUDITOR SEBAGAI PEMODERASI ( Studi Kasus pada Inspektorat Kota Bogor dan Depok )
}

\author{
Yunita Kurnia Shanti \\ Dosen Program Studi Akuntansi, Universitas Pamulang \\ email : kurniay25@gmailcom
}

\begin{abstract}
This research aimed was to examine the impact of self efficacy on audit judgement with auditor senior as moderate variable at inspectorat of bogor city and depok city. This research is done to prove the influence of these variable on audit judgement. This population is goverment internal auditor at inspectorat of bogor city and depok cityS in west java. Samples were taken by convenience sampling pursuant to amenity acces and availability of respondent. Amount of sample is 41 respondent can be to test. Statistical data analysis method used is simple linear regression and multiple regression analysis. The hypotesis of this research is divided into two, self efficacy of audit judgement, and self efficacy on audit judgement with auditor senios as moderate variable. The result of this research shows that self efficacy have significant influenced on audit judgement. It means more auditors is confident in capability they have, will be better the audit judgement. Self efficacy have no significant influenced on audit judgement with senior auditor as moderate variable. Its show that audit judgement must be supported by self confident but not only carried out by the senior auditor but all auditors in the audit assignment.
\end{abstract}

Keywords : self efficacy, audit judgement, senioritas auditor

\section{PENDAHULUAN}

Setiap entitas dalam pencapaian tujuannya diharapkan mampu meminimalisir resiko yang dihadapi. Bagaimana mendeteksi area atau fungsi yang mempunyai resiko tinggi yang kemungkinan dapat mengganggu pencapaian tujuan maka dibutuhkan peran pengawasan internal. Fungsi audit internal menurut Ardeno Kurniawan (2012:53) adalah memberikan berbagai macam jasa kepada organisasi termasuk kinerja dan auditor operasional yang akan dapat membantu manajemen senior dan dewan komisaris dalam memantau kinerja yang dihasilkan oleh manajemen dan para personil di dalam organisasi sehingga auditor internal dapat memberikan penilaian yang independen mengenai seberapa baik kinerja organisasi. Secara umum fungsi audit internal adalah untuk memberikan penilaian terhadap seberapa efisien suatu pengendalian internal di dalam organisasi dan bukan hanya terfokus kepada pencarian ketepatan dan kebenaran atas catatan-catatan akuntansi saja tetapi juga melakukan suatu penelitian dari berbagai operasional yang terjadi di dalam organisasi.

Pengendalian internal juga mempengaruhi kondisi didalam perusahaan, dimana bagian yang rentan akan kecurangan tidak mendapatkan pengawasan yang kurang sehingga para oknum didalam perusahaan bisa menggunakan celah tersebut untuk melakukan kecurangan demi mendapatkan keuntungan individu atau kelompok tertentu. Hasil akhir dalam proses audit yang dilakukan oleh auditor internal adalah memberikan rekomendasi dengan judgement yang didasarkan pada kejadian-kejadian di masa lalu, sekarang dan yang akan datang. Sebagaimana dinyatakan dalam Standar Profesional Akuntansi Publik (SPAP, 2001) pada seksi 341 paragraf 6, dalam pelaksanaan prosedur seperti yang disebutkan dalam paragraf ke 5 , auditor dapat mengidentifikasikan informasi mengenai kondisi dan peristiwa tertentu yang jika dipertimbangkan secara keseluruhan, menunjukan adanya kesangsian besar tentang kemampuan enititas dalam mempertahankan kelangsungam hidupnya dalam jangka waktu pantas. auditor internal juga harus memiliki audit judgement yang baik pula untuk mendapatkan opini wajar tanpa pengecualian (WTP) oleh audit eksternal pemerintah. Karena 
auditor internal dalam tugasnya memeriksa keadaan sebuah organisasi dan membenahi kondisinya sebelum auditor eksternal memeriksa organisasi tersebut. Audit judgement merupakan suatu pertimbangan pribadi atau cara pandang auditor dalam menanggapi informasi yang mempengaruhi dokumentasi bukti serta pembuatan keputusan pendapat auditor atas laporan keuangan suatu entitas.

Ketenangan dalam berpikir dan mempertimbangankan sebelum mengambil keputusan biasanya biasanya dilakukan oleh auditor senior dilihat dari pengalamannya. Semakin lama auditor bekerja maka semakin banyak pula pengalaman yang dimiliki oleh seorang auditor. Senioritas merupakan perferensi dalam posisi dimana seseorang yang sudah lebih berpengalaman pada bidang yang ditekuninya (Mulyana, 2012). Self-efficacy yang dimiliki oleh seorang biasanya dikarenakan tingkat pendidikan yang tinggi, pengalaman yang matang, keahlian yang baik sehingga keyakinan orang tersebut juga semakin meningkat. Selain itu juga tidak jarang sifat itu timbul karena banyaknya orang yang lebih ahli di sekitarnya atau dilingkunganya sehingga keyakinanya pun meningkat, tetap ini tidak bisa dijadikan tolak ukur tingginya Self-efficacy seseorang. Seorang individu dengan memiliki self-efficacy yang tinggi akan senantiasa lebih cenderung untuk mempertimbangkan, mengevaluasi, dan menggabungkan kemampuan yang diketahuinya sebelum menentukan pilihan.

Menurut Valery G. Kumaat (2010:12) dalam peran internal audit setidaknya terdapat area yang tidak terpisahkan dalam pelaksanaan fungsinya yaitu pengembangan manajemen resiko, pengembangan pengendalian internal dan pengintegrasian unit-unit kerja bisnis. penelitian yang dilakukan oleh Wijaya (2012) sendiri yang mengatakan bahwa self-efficacy berpengaruh positif terhadap audit judgement. Seorang individu dengan memiliki self-efficacy yang tinggi akan senantiasa lebih cenderung untuk mempertimbangkan, mengevaluasi, dan menggabungkan kemampuan yang diketahuinya sebelum menentukan pilihan. Penelitian fitriana, kamilian dan sulastri (2014) menunjukan bahwa senioritas auditor berpengaruh terhadap audit judgment. Dalam penyelesaian tugas-tugas yang diberikan senior auditor lebih memiliki ketenangan dan kematangan, karena didalam melakukan suatu tugas auditor tersebut menggunakan pengalaman dan keahlian yang sudah didapat sebelumnya. Dalam penelitian ini ingin menguji dan membuktikan pengaruh self efficacy terhadap audit judgement dengan dimoderasi oleh senioritas auditor.

\section{TINJAUAN PUSTAKA}

\section{Teori Sikap dan Perilaku Etis}

Perilaku etis adalah perilaku yang sesuai dengan norma - norma sosial yang diterima secara umum, berhubungan dengan tindakan - tindakan yang bermanfaat dan membahayakan. Perilaku kepribadian merupakan karakteristik individu dalam menyesuaikan diri dengan lingkungan, yang meliputi sifat, kemampuan, nilai, keterampilan, sikap, dan intelegensi yang muncul dalam pola perilaku seseorang. Dapat disimpulkan bahwa perilaku merupakan perwujudan atau manifestasi karakteristik - karakteristik seseorang dalam menyesuaikan diri dengan lingkungan (Maryani dan Ludigdo (2000) dalam Deni Samsudin (2010: 3). Perilaku kepribadian merupakan karakteristik individu dalam menyesuaikan diri dengan lingkungan, yang meliputi sifat, kemampuan, nilai, keterampilan, sikap, dan intelegensi yang muncul dalam pola perilaku seseorang.Teori ini berusaha menjelaskan mengenai aspek perilaku manusia dalam suatu organisasi, khususnya akuntan publik atau auditor yaitu meneliti bagaimana perilaku auditor dengan adanya faktor-faktor yang mempengaruhi independensi auditor. Sikap yang dimaksud disini adalah sikap auditor dalam berperilaku independen dan objektif dalam penampilan ketika auditor tersebut memiliki sikap independensi yang tinggi saat melaksanakan audit. Auditor diwajibkan bersikap independen yaitu sikap tidak memihak kepentingan siapapun, dan objektif yaitu sikap yang menyajikan hasil audit sesuai dengan fakta. Dengan auditor memiliki sikap perilaku etis yang baik maka keyakinan terhadap kemampuan diri juga semakin meningkat serta diharapkan pertimbangan auditnya semakin baik. 


\section{Self Efficacy, senioritas Auditor dan Audit Judgement}

Menurut Bandura dan Wijayantini (2014) self efficacy merupakan suatu kepercayaan seseorang bahwa dia dapat menjalankan sebuah tugas pada tingkat tertentu, yang nantinya akan dapat mempengaruhi aktifitas pribadinya terhadap pencapaian suatu tugas. Tingginya self efficacy yang dimilikinya oleh seseorang akan membuat keraguan diri terhadap kemampuan orang tersebut menjadi lebih sedikit dan cenderung untuk tidak menyerah serta mengatasi setiap tantangan dengan usaha yang lebih besar. Auditor harus dapat meningkatkan kemampuan dan keyakinan diri sehingga dapat menyesuaikan diri dengan lingkungan Seorang auditor dengan self efficacy atau keyakinan diri yang baik diharapkan mampu menyelesaikan penugasan auditnya dengan judgement yang lebih baik.

Senioritas auditor selain menunjukkan lamanya bekerja atau masa tugas dari auditor tersebut, juga memberikan gambaran tentang pengalaman dan pengetahuan yang dimiliki auditor (Mulyana, 2012). Asumsinya yaitu semakin senior auditor tersebut, maka semakin banyak pula pengalaman dan pengetahuan yang dimiliki tentang proses audit, sehingga judgement yang dihasilkan akan relatif lebih baik dibanding dengan auditor yang baru dalam melaksanakan audit (Rahayu, 2014). Semakin luas pengalaman seseorang, semakin terampil melakukan pekerjaan dan semakin sempurna pola berpikir dan sikap dalam bertindak untuk mencapai tujuan yang telah ditetapkan. Semakin lama seorang auditor senior dalam pengalaman auditnya diharapkan semakin mampu menghasilkan kinerja yang lebih baik dalam penugasan auditnya. Auditor yang lebih senior akan membuat judgement yang relatif lebih baik dalam tugas-tugas profesional dibanding auditor yang belum senior.

Judgement merupakan suatu proses yang terus-menerus dalam perolehan informasi, (termasuk umpan balik dari tindakan sebelumnya) pilihan untuk bertindak atau tidak bertindak, dan penerimaan informasi lebih lanjut. Audit judgement merupakan suatu pertimbangan pribadi atau cara pandang auditor dalam menanggapi informasi yang mempengaruhi dokumentasi bukti serta pembuatan keputusan pendapat auditor atas laporan keuangan suatu entitas. Menurut (Jamilah, dkk, 2007) audit judgement adalah kebijakan auditor dalam menentukan pendapat mengenai hasil auditnya yang mengacu pada pembentukan suatu gagasan, pendapatan atau perkiraan tentang suatu objek, peristiwa, status, atau jenis peristiwa lainya. Proses judgement tergantung pada kedatangan informasi yang terus menerus, sehingga dapat mempengaruhi pilihan dan cara pilihan tersebut dibuat. Setiap langkah dalam proses incremental judgement, jika informasi terus menerus datang akan muncul pertimbangan baru dan keputusan atau pilihan baru.

\section{METODE}

\section{Populasi dan Sampel}

Adapun jenis penelitian yang digunakan adalah penelitian kuantitatif dengan data primer. Menurut Sugiyono (2014:193) sumber data primer adalah sumber data yang langsung memberikan data kepada pengumpul data. Populasi dalam penelitian ini adalah auditor yang bekerja pada Inspektorat Pemerintah Kota Depok dan Kota Bogor sebagai responden. Dalam penelitian ini peneliti menyebarkan kuisioner kepada kepada responden dengan sampel penelitian sebanyak 72 sampel. Teknik pengambilan sampel yang digunakan dalam penelitian ini adalah convinience sampling.

Convinience sampling adalah sampel yang dipilih dengan pertimbangan kemudahan dengan mengambil responden sebagai sampel berdasarkan dengan kedekatan jarak dan aksesibilitas peneliti dengan sampel (Sugiyono; 2014:118). Dalam teknik pengambilan sampel ini jumlah populasi sama dengan sampel. Sampel dapat digunakan oleh peneliti apabila responden tersebut sesuai dengan kriteria utama yang ditetapkan oleh peneiliti.

\section{Variabel Penelitian dan Metode Analisis}

Variabel penelitian merupakan sesuatu yang ditetapkan oleh peneliti untuk dipelajari sehingga diperoleh informasi tentang hal tersebut yang kemudian ditarik kesimpulannya (Sugiyono; 2014:63). Skala pengukuran variable menggunakan skala likert yaitu variabel yang akan diukur dijabarkan menjadi indikator variabel. Kemudian indikator tersebut 
dijadikan sebagai titik tolak ukur menyusun item - item instrumen yang dapat berupa pertanyaan atau pernyataan. Variabel ini diukur dengan menggunakan skala likert 5 poin meliputi $1=$ sangat tidak setuju, $2=$ tidak setuju, $3=$ ragu-ragu, $4=$ setuju, 5= sangat setuju.

Variable penelitian yang digunakan adalah variable terikat (dependen) yang digunakan dalam penelitian ini adalah audit judgement dengan indicator variable meliputi kebijakan auditor dalam menentukan pendapat mengenai hasil auditnya yang mengacu pada pembentukan suatu gagasan, pendapat atau perkiraan tntang suatu objek, tanggapan terhadap suatus peristiwa/ asersi. Dan variable bebas (independen) yang digunakan yaitu self efficacy dengan indikator variabel meliputi sifat saat melakukan tugas yang dihadapi, imbalan yang diberikan atas kemampuan diri yang dimiliki, peran individu dalam lingkungan pekerjaannya. Dalam penelitian ini peneliti menambahkan variabel moderasi yaitu senioritas auditor dengan indikator variabel meliputi struktur organisasi pada inspektorat, lama auditor tersebut bertugas, kemampuan memberikan pertimbangan audit pada saat penugasan.

Tehnik analisis data yang digunakan meliputi statistik diskriptif (Ghozali; 2013:19) uji deskriptif memberikan gambaran atau deskripsi suatu data yang dilihat dari nilai rata-rata (mean), standar deviasi, maksimum dan minimum. Untuk menguji kualitas data kuisioner peneliti menggunakan uji validitas dan reliabilitas, yang mana memastikan valid tidaknya suatu kuisioner dan handal konsisten dari suatu pernyataan. Uji asumsi klasik merupakan pengujian asumsi-asumsi statistik yang harus dipenuhi pada analisis regresi linier sederhana dan MRA meliputi uji normalitas, uji heterokedasitas dan uji multikolonieritas. Pengujian hipotesis dengan analisis regresi linear sederhana dan MRA (multiple regresi analisyst). Regresi linear sederhana untuk menguji pengaruh self efficacy terhadap audit judgement, dan MRA digunakan untuk menguji pengaruh self efficacy terhadap audit judgement dengan dimoderasi senioritas auditor dengan bantuan program komputer SPSS 22. Persamaan yang dibentuk adalah sebagai berikut :

$\mathrm{Y}=\alpha+\beta 1 \mathrm{X} 1+\beta 2 \mathrm{X} 1 \mathrm{Z}$

\section{Teknik Analisis Data}

Metode analisis data yang digunakan dalam penelitian ini adalah metode analisis statistik. Tujuan dari analisis data adalah untuk mendapatkan informasi relevan yang terkandung didalam data tersebut dan digunakakan untuk memecahkan suatu masalah. Pengujian yang dilakukan adalah sebagai berikut :

a. Uji kualitas data yaitu validitas dan reliabilitas

b.Uji statistik dekriptif

c. Uji asumsi klasik yaitu normalitas, heterokedasitas dan multikoloniaritas

d.Uji koefisien determinasi

e. Uji regresi sederhana

f. Uji MRA

\section{HASIL DAN PEMBAHASAN}

Berikut akan dipaparkan hasil dan pembahasan penelitian sesuai tehnik analisa data yang digunakan oleh peneliti. Objek penelitian ini adalah auditor yang bekerja pada Inspektorat Pemerintah Kota Depok dan Kota Bogor. semua responden yang didapat dari penyebaran kuesioner di Inspektorat Kota Bogor dan Kota Depok. Jumlah sampel dalam penelitian ini berjumlah 41 responden yang meliputi 26 auditor Kota Bogor dan 15 auditor Kota Depok dimana semua responden mengembalikan kuesioner dan memenuhi kelengkapan sampel yang dibutuhkan. Jumlah sampel yang didapat berjumlah 41 sampel data dengan jumlah pria sebanyak 18 responden dengan presentase sebesar $44 \%$ sedangkan responden wanita sebanyak 23 responden dengan presentase sebesar $56 \%$.

Jabatan para responden dalam inspektorat yaitu diperoleh informasi bahwa mayoritas responden 20 orang atau sebesar $48,8 \%$ menduduki posisi sebagai auditor. Responden yang menduduki jabatan sebagai auditor muda 14 orang atau $34,1 \%$, sedangkan sisanya yaitu sebagai auditor madya dan auditor jabatan fungsional masing-masing sebesar 3 dan 4 orang 
atau sekitar 7,3\% dan 9,8\%. Selanjutnya penulis akan menguraikan lama bekerja semua reponden dalam Inspektorat, lama bekerja yang tidak diketahui sebanyak 7 responden dengan presentase sebesar $17 \%$, responden yang bekerja dibawah 1 tahun tidak ada, lama bekerja berkisar 1 sampai 5 tahun didapat sebanyak 9 responden dengan presentase sebesar 22\%, lama bekerja responden yang bekerja selama 6 sampai 10 tahun sebanyak 11 responden dengan presentse sebesar 27\%, sedangkan jumlah responden yang bekerja diatas 10 tahun sebanyak 14 responden dengan presentase sebesar $34 \%$.

\section{Uji Kualitas Data \\ Uji Validitas}

Berdasarkan hasil uji validitas pada variable moderasi senioritas auditor memiliki pearson correlation dari $0,457-0.882$. Variable independen self efficacy memperoleh pearson correlation dari 0,353 - 1. Dan variable dependen audit judgement memperoleh pearson correlation dari $0,368-0,798$. Seluruh variable bebas, vaiabel moderasi dan variable terikat menunukkan hasil pearson correlation lebih besar dari 0,3 yang berarti bahwa peryataanpernyataan dalam kuesioner tersebut valid.

\section{Uji Reliabilitas}

Hasil uji reliabilitas pada variable moderasi senioritas auditor menujukkan koefisien cronbach's alpha 0.875. pada variable indepeden self efficacy menunjukkan koefisien cronbach's alpha 0.892. Dan untuk variable dependen audit judgement menjunjukkan koefisien Cronbach's alpha 0.854. Seluruh hasil koefisien cronbach's alpha pada variable moderasi, variable bebas dan variable terikat menunjukkan lebih dari 0,6 sehingga dikatakan seluruh pernyataan-pernyataan dalam kuestioner tersebut reliabel.

\section{Statistik Deskriptif}

\begin{tabular}{|l|r|r|r|r|r|}
\hline & Tabel 1 Descriptive Statistics & \multicolumn{1}{c|}{ Std. Deviation } \\
\hline SE & Minimum & Maximum & Mean & 4.16826 \\
AJ & 41 & 30.00 & 49.00 & 39.0244 & 3.49250 \\
SA & 41 & 30.00 & 49.00 & 38.9512 & 3.91027 \\
Valid N & 41 & 16.00 & 35.00 & 26.0976 & \\
(listwise) & 41 & & & & \\
\hline
\end{tabular}

Pada table 1 menunjukkan hasil analisis dengan menggunakan statistik deskriptif terhadap variabel Senioritas Auditor menunjukan nilai minimum sebesar 16, nilai maksimum sebesar 35, nilai rata-rata sebesar 26,09 dengan standar deviasi 3,910. Selain itu, variabel Self Efficacy dengan nilai minmum sebesar 30, nilai maksimum 49, nilai rata-rata sebesar 39,02 dengan standar deviasi sebesar 4,168. Dan untuk hasil variabel y yaitu audit judgement dengan nilai minimum 30, nilai maksimum sebesar 50, nilai rata-rata 40,20 dengan standar deviasi sebesar 4,020.

\section{Uji Asumsi Klasik}

Uji Asumsi klasik dilakukan guna mengetahui layak atau tidaknya suatu data dalam penelitian untuk dianalisis, uji asumsi klasik ini bertujuan untuk memberikan kepastian bahwa persamaan regresi yang didapatkan memiliki ketepatan dalam estimasi, tidak bias dan konsisten. Uji asumsi klasik yang digunakan dalam penelitian ini antara lain Uji Normalitas, Uji Multikolonieritas, dan Uji Heterokedastisitas.

\section{Uji Normalitas}

Uji Normalitas dilakukan dengan tujuan untuk menguji apakah dalam model regresi, variabel pengganggu atau residual memiliki distribusi normal (Ghozali, 2013:154). Jika terdapat normalitas, maka residual akan terdistribusi secara normal 
dan independen, medel regresi yang baik adalah yang memilikai distribusi data normal atau mendekati normal. Dalam penelitian ini, uji normalitas dilakukan menggunakan metode Non-Parametic Kolmogorov Smirnov $(K-S)$.

Tabel 2 One-Sample Kolmogorov-Smirnov Test

\begin{tabular}{|c|c|c|}
\hline & Unstandardized Residual \\
\hline $\begin{array}{l}\text { N } \\
\text { Normal } \\
\text { Parameters } \\
\text { Most Extreme } \\
\text { Differences } \\
\text { Test Statistic } \\
\text { Asymp. Sig. (2- }\end{array}$ & $\begin{array}{l}\text { Mean } \\
\text { Std. Deviation } \\
\text { Absolute } \\
\text { Positive } \\
\text { Negative }\end{array}$ & $\begin{array}{r}41 \\
.0000000 \\
3.08020291 \\
.100 \\
.082 \\
-.100 \\
.100 \\
.200^{\mathrm{c}, \mathrm{d}} \\
\end{array}$ \\
\hline
\end{tabular}

a. Test distribution is Normal.

b. Calculated from data.

c. Lilliefors Significance Correction.

d. This is a lower bound of the true significance.

Pada table 2 menunjukkan hasil metode uji Kolomogorov-Smirnov $(K-S)$ dengan melihat nilai propabilitas dignifikansi data residual, jika angka probabilitasnya kurang dari 0,05 maka variabel ini berdistribusi secara tidak normal. Sebaliknya, jika propabilitas diatas nilai 0,05 maka data dapat dikatan telah berdistribusi secara normal. Hasil uji KolomogorovSmirnov $(K-S)$ menunjukkan bahwa nilai Asymp. Sig (2-Tailed) sebesar 0,200 yang berarti lebih besar dibanding dengan 0,05 sehingga model penelitian ini telah memenuhi uji asumsi klasik normalitas.

\section{Uji Multikolinieritas}

Uji Multikolinieritas bertujuan untuk menguji apakah model regresi ditemukan adanya korelasi antara variabel bebas (independen) dalam model regresi (Ghozali, 2013:103). Model regresi dikatakan baik apabila tidak terjadi korelasi antar variabel independen. Untuk menditeksi adanya msalah Multikolinieritas dalam penelitian ini menggunakan Tolerance Value atau Nilai Toleransi dan Variance Infaction Factor $(V I F)$. Regresi yang terbebas dari masalah Multikolinieritas yaitu apabila VIF $<10$ dan Tolerance $>0,1$, maka data tersebut tidak ada masalah Multikolinieritas.

Tabel 3 Coefficients ${ }^{a}$

\begin{tabular}{|l|r|r|}
\hline \multirow{2}{*}{ Model } & \multicolumn{2}{|c|}{ Collinearity Statistics } \\
\cline { 2 - 3 } (Constant) & Tolerance & \multicolumn{1}{|c|}{ VIF } \\
SE & & \\
SA & .984 & 1.016 \\
\end{tabular}

a. Dependent Variable: AJ

Berdasarkan Tabel 4.3 diatas dapat diketahui bahwa data dalam penelitian ini tidak terdapat multikolinieritas. Hal ini dapat dibuktikan dari hasil nilai Tolerance yang lebih besar dari 0,1 dengan nilai variabel senioritas auditor sebesar 0,984 dan nilai variabel self efficacy sebesar 0,984. Selain itu pembuktian lewat nilai VIF yang lebih kecil dari 10 dengan nilai variabel senioritas auditor sebesar 1,016, nilai variabel self efficacy sebesar 1,016, ini membuktikan bahwa semua variabel independen tidak terjadi masalah multikolonieritas karena masing-masing variabel memiliki nilai tolerance lebih besar dari 0,1 dan nilai VIF lebih kecil dari 10.

\section{Uji Heterokedasitas}

Untuk mengetahui ada atau tidaknya heteroskedastisitas, dalam penelitian ini dilakukan uji statistik dengan menggunakan Uji Glejser. Dimana akan dikatakan terbebas dari 
heteroskedasitas apabila nilai signfikansinya diatas $5 \%(\mathrm{sig}>0,05)$.

\begin{tabular}{|c|c|c|c|c|c|c|}
\hline \multirow{2}{*}{\multicolumn{2}{|c|}{ Model }} & \multicolumn{2}{|c|}{ Unstandardized Coefficients } & \multirow{2}{*}{$\begin{array}{c}\begin{array}{c}\text { Standardized } \\
\text { Coefficients }\end{array} \\
\text { Beta }\end{array}$} & \multirow[b]{2}{*}{$\mathrm{T}$} & \multirow[b]{2}{*}{ Sig. } \\
\hline & & $\mathrm{B}$ & Std. Error & & & \\
\hline 1 & (Constant) & 3.965 & 3.826 & & 1.036 & .307 \\
\hline & SE & -.060 & .075 & -.130 & -.802 & .427 \\
\hline & SA & .029 & .080 & .058 & .361 & .720 \\
\hline
\end{tabular}

a. Dependent Variable: AJ

Hasil Uji Heteroskedastisitas dengan menggunakan Uji Glejser dapat dilihat pada Tabel 4.4 dimana nilai signifikansi variabel-variabel tersebut memiliki nilai yang lebih dari 0,05 dengan nilai variabel senioritas auditor sebesar 0,720 , nilai dari variabel self efficacy sebesar 0,427. Ini membuktikan bahwa variabel tersebut terbebas dari Heterokedastisitas karena masing-masing variabel memiliki nilai yang lebih dari 0,05 .

\section{Uji Hipotesa Sebelum MRA \\ Uji Koefisien Determinasi}

Koefesien Derteminan $\left(\mathrm{R}^{2}\right)$ pada intinya mengukur seberapa jauh kemampuan model regresi dalam menerangkan pengaruh variabel independen terhadap variabel dependen. Dalam penelitian ini menggunakan variabel independen self efficacy dengan variabel dependen audit judgement.

Tabel 5.Model Summaryb

\begin{tabular}{|c|c|c|c|c|}
\hline Model & $\mathrm{R}$ & R Square & Adjusted R Square & Std. Error of the Estimate \\
\hline 1 & $.386^{\mathrm{a}}$ & .149 & .128 & 3.26216 \\
\hline
\end{tabular}

Pada tabel 4.14 Uji Koefesien Determinan bisa kita lihat nilai Adjust $R$ Square sebesar 0,128 atau dalam presentase sebesar 12,8\% variabel audit judgement dapat dijelaskan atau dipengauhi oleh variabel self efficacy. Sedangkan sisanya sebesar 87,2\% dijelaskan oleh faktor-faktor lain yang tidak termasuk dalam analisa regresi pada penelitian ini.

Tabel 6. Coefficients ${ }^{a}$

\begin{tabular}{|c|c|c|c|c|c|c|c|}
\hline \multirow[b]{2}{*}{ Model } & \multicolumn{2}{|c|}{$\begin{array}{c}\text { Unstandardized } \\
\text { Coefficients }\end{array}$} & \multirow{2}{*}{$\begin{array}{c}\begin{array}{c}\text { Standardized } \\
\text { Coefficients }\end{array} \\
\text { Beta }\end{array}$} & \multirow[b]{2}{*}{$\mathrm{T}$} & \multirow[b]{2}{*}{ Sig. } & \multicolumn{2}{|c|}{$\begin{array}{c}\text { Collinearity } \\
\text { Statistics } \\
\end{array}$} \\
\hline & $\mathrm{B}$ & Std. Error & & & & Tolerance & VIF \\
\hline $\begin{array}{ll}1 & \text { (Constant } \\
& \text { SE }\end{array}$ & $\begin{array}{r}26.314 \\
.324\end{array}$ & $\begin{array}{r}4.856 \\
.124\end{array}$ & .386 & $\begin{array}{l}5.419 \\
2.617\end{array}$ & $\begin{array}{l}.000 \\
.013\end{array}$ & 1.000 & 1.000 \\
\hline
\end{tabular}

a. Dependent Variable: AJ

Dalam penelitian ini dilakukan analisisi regresi linier sederhana untuk mengetahui ada atau tidaknya pengaruh variabel bebas (independen) terhadap variabel terikat (dependen). Variabel Self Efficacy ditentukan dengan melihat nilai signifikansi di tabel Coefficients yaitu dengan nilai 0,013 , dibanding dengan 0,05 maka nilai signifikansi lebih kecil dibanding dengan $0,05(0,013<0,05)$ berarti Self Efficacy berpengaruh secara signifikan terhadap Audit judgement. 


\section{Uji Hipotesa Setelah MRA}

\begin{tabular}{|l|r|r|r|r|}
\hline Model & \multicolumn{1}{|c|}{ Tabel 7 Model Summaryb } \\
\hline 1 & $.472^{\mathrm{a}}$ & R Square & \multicolumn{1}{c|}{ Adjusted R Square } & Std. Error of the Estimate \\
\hline
\end{tabular}

a. Predictors: (Constant), SE* SA, SE, SA

b. Dependent Variable: AJ

Pada tabel 7 Uji Koefesien Determinan setelah moderasi bisa kita lihat nilai Adjust $R$ Square sebesar 0,160 atau dalam presentase sebesar $16 \%$ variabel audit judgement dapat dijelaskan atau dipengauhi oleh variabel self efficacy, sedangkan sisanya sebesar $84 \%$ dijelaskan oleh faktor-faktor lain yang tidak termasuk dalam analisa regresi pada penelitian ini.

Tabel 8. Coefficient

\begin{tabular}{|c|c|c|c|c|c|}
\hline \multirow[b]{2}{*}{ Model } & \multicolumn{2}{|c|}{ Unstandardized Coefficients } & \multirow{2}{*}{$\begin{array}{c}\text { Standardized } \\
\text { Coefficients } \\
\text { Beta }\end{array}$} & \multirow[b]{2}{*}{$\mathrm{T}$} & \multirow[b]{2}{*}{ Sig. } \\
\hline & $\mathrm{B}$ & Std. Error & & & \\
\hline 1 (Constant) & 27.485 & 31.757 & & .865 & .392 \\
\hline SE & .454 & .796 & .542 & .571 & .572 \\
\hline SA & -.001 & 1.204 & -.001 & -.001 & .999 \\
\hline$S E^{*} \mathrm{SA}$ & -.006 & .030 & -.312 & -.202 & .841 \\
\hline
\end{tabular}

a. Dependent Variable: AJ

Dalam penelitian ini dilakukan uji multiple regresi analisyst (MRA) untuk mengetahui apakah senioritas auditor memperkuat pengaruh self efficacy terhadap audit judgement. Berdasarkan Tabel 8 kooefisien memperoleh hasil bahwa nilai signifikansi self efficacy dengan dimoderasi oleh senioritas auditor lebih besar dari 0,05 yaitu 0,841 . Hal ini menunjukkan bahwa variable moderasi senioritas auditor memperlemah pengaruh self efficacy terhadap audit judgement.

\section{Pembahasan}

\section{Pengaruh self efficacy terhadap audit judgement}

Hasil Uji Regresi sederhana bisa kita lihat bahwa untuk variabel Self Efficacy ditentukan dengan melihat nilai signifikansi di tabel Coefficients yaitu dengan nilai 0,013 sehingga diperoleh hasil signifikansi lebih kecil dibanding dengan $0,05(0,013<0,05)$ berarti Self Efficacy berpengaruh secara signifikan terhadap Audit judgement. Diharapkan bahwa seorang auditor yang memiliki sifat self efficacy cenderung mempunyai keyakinan diri yang tinggi dan dapat memotivasi untuk berkontribusi lebih dalam menentukan pertimbangan audit yang lebih baik pada saat penugasan audit. Penelitian ini mendukung penelitian yang dilakukan oleh Mahaputra (2016) dan Wijayantini (2014).

\section{Pengaruh self efficacy terhadap audit judgement dengan dimoderasi senioritas auditor}

Hasil uji multiple regresi analisyst (MRA) menunjukkan hasil bahwa nilai signifikansi self efficacy dengan dimoderasi oleh senioritas auditor lebih besar dari 0,05 yaitu 0,841 . Hal ini berarti bahwa variable moderasi senioritas auditor tidak mampu memperkuat pengaruh variable self efficacy terhadap audit judgement. Seorang auditor dalam menjalankan penugasan auditnya memerlukan keyakinan diri yang tinggi untuk mendukung pertimbanganpertimbangan audit yang diambilnya dalam penyelesaian audit tetapi hal ini tidak terbatas hanya pada auditor senior saja. Semua auditor dalam penugasannya tidak terbatas senior ataupun junior auditor dapat menentukan petimbangan audit yang diambilnya dalam mendukung pembuatan keputusan dalam penyelesaian audit.

\section{SIMPULAN}

Berdasarkan pada data dan hasil dari penelitian yang telah diuraikan sebelumnya, maka dapat ditarik kesimpulan sebagai berikut : 
1. Self Efficacy mempunyai nilai signifikansi lebih kecil dibanding dengan 0,05 yaitu 0,013 $<0,05$ sehingga Self Efficacy berpengaruh secara signifikan terhadap Audit judgement. Penelitian ini mendukung penelitian yang dilakukan sebelumnya oleh Mahaputra (2016) dan Wijayantini (2014).

2. Hasil nilai signifikansi self efficacy dengan dimoderasi oleh senioritas auditor lebih besar dari 0,05 yaitu 0,841 . Hal ini menunjukkan bahwa variable moderasi senioritas auditor memperlemah pengaruh self efficacy terhadap audit judgement.

\section{SARAN}

Untuk penelitian yang akan dating, peneliti memberikan masukan sebagai berikut :

1. Penelitian selanjutnya dapat menambah variabel-variabel yang lebih berpengaruh terhadap audit judgement. Sebagai contoh keahlian, pengalaman dan kompetensi.

2. Penelitian selanjutnya mampu menggunakan variable moderasi yang lain, sehingga memberikan hasil memperkuat pengaruh variable independen terhadap dependen.

3. Diharapkan dapat memperluas wilayah penelitian (populasi) untuk mendapatkan responden yang lebih banyak.

4. Tidak hanya menggunakan data yang berasal dari survei melalui kuisioner. Sebaiknya digunakan juga metode wawancara agar dapat mendukung hasil yang diperoleh melalui metode kuisioner.

\section{DAFTAR PUSTAKA}

Agoes, Sukrisno. 2012 “Auditing Petunjuk Praktis Pemeriksaan Akuntan Oleh Akuntan Publik", Jilid 1, Edisi Keempat, Salemba Empat, Jakarta.

Agustian,N.,Merkusiwati,N. 2016 Pengaruh Tekanan Ketaatan, Senioritas Auditor Dan Tekanan Anggaran Waktu Terhadap Audit Judgement, Fakultas Ekonomi Dan Bisnis, Universitas Udayana.Bali

Fitriana,Rahayu. 2014 Pengaruh Kompleksitas Tugas, Tekanan Ketaatan, Tingkat Senioritas Auditor, Keahlian Auditor, Dan Hubungan Dengan Klien Terhadap Audit Judgement, Akuntansi, Fakultas Ekonomi. Universitas Riau. Sumatra.

Ghozali,Imam. 2013 Aplikasi Analisis Multivariat dengan Program IBM SPSS. 21. Edisi 7, Penerbit Universitas Diponegoro, Semarang

Idris,Fitriani Seni. 2012 Pengaruh Tekanan Ketaatan, Kompleksitas Tugas, Pengetahuan,Dan Persepsi Etis Terhadap Audit Judgement, Fakultas Ekonomi dan Bisnis,Universitas Diponegoro.Semarang,

Ikatan Akuntansi Indonesia. 2001 Standar Profesional Akuntan Publik, Penerbit Salemba 4,Jakarta.

Sawyer, Lawrence B., Mortimer A. Dittenhofer, dan James H. Scheiner. 2005. Sawyer's Internal Auditing 5th Edition. Dialihbahasakan oleh Desi Adhariani. Audit Internal Sawyer. Edisi 5. Buku 1. Salemba Empat. Jakarta.

Liana,M.,Tjondro,Elisa. 2014 Pengaruh Tekanan Ketaatan, Pengalaman Audit, Dan Audit Tenure Terhadap Audit Judgement. Program Akuntansi Pajak Prgram Studi Akuntansi. Universitas Kristen Petra. Surabaya.

Mahaputra, I Nyoman Kusuma Adnyana. 2016 Pengaruh Locus Of Control, Self Esteem, Self Efficacy Dan Tingkat Pendidikan Terhadap Kinerja Auditor Dalam Pembuatan Audit Judgement Pada Kantor Akuntan Publik Di Bali, Universitas Mahasaraswati Denpasar.Bali,

Mulyana, Refini. (2012) Pengaruh Kompleksitas Tugas, Tekanan Ketaatan, Tingkat Senoritas Auditor, Dan Hubungan dengan klien Terhadap Audit Judgement. Universitas Riau. Pekanbaru. 
Nadhiroh, Siti Asih. (2010) Pengaruh Kompleksitas tugas, Orientasi Tujuan, Dan Self Efficacy Terhadap Kinerja Auditor Dalam Pembuatan Audit Judgement (Studi Pada Kantor Akuntan Publik Di Semarang). Universitas Diponegoro. Semarang Sugiyono. (2014) Metode Penelitian Kuantitatif Kualitatif dan R\&D. Bandung : Alfabeta.

Wijayantini,K.,Yuniarta,G.,Atmandja,A. (2014) Pengaruh Tekanan Ketaatan, Kompleksitas Tugas, Dan Self Efficacy Terhadap Audit Judgement, Universitas Pendidikan Ganesha.Bali, 